\title{
IDENTIFIKASI KESALAHAN BERPIKIR VISUAL MAHASISWA DALAM MENGGAMBAR GRAFIK FUNGSI REAL
}

\author{
Darmadi \\ FKIP Universitas PGRI Madiun \\ darmadi.mathedu@unipma.ac.id
}

\begin{abstract}
Abstrak: Untuk memahami konsep dan prosedur pembuktian keintegralan suatu fungsi, mahasiswa perlu mengetahui gambaran konsep dari fungsi dan gambaran prosedur dari tiap-tiap langkahnya. Berpikir dengan menggunakan gambaran konsep dan gambaran prosedur menunjukkan mahasiswa telah berpikir visual. Makalah ini membahas hasil analisis kesalahan berpikir visual mahasiswa program studi pendidikan matematika Universitas PGRI Madiun dalam menggambarkan grafik fungsi.
\end{abstract}

Kata Kunci: berpikir visual, menggambar grafik fungsi

Analisis real dan kalkulus merupakan salah satu mata kuliah wajib bagi mahasiswa program studi pendidikan matematika di FKIP Universitas PGRI Madiun. Analisis real dan kalkulus membahas turunan dan integral fungsi. Seperti mata kuliah yang lainnya, analisis real dan kalkulus tidak dapat dilepaskan dari fungsi.

Fungsi adalah relasi yang menghubungkan semua anggota domain tepat satu (secara unik) ke anggota kodomain. Fungsi yang tidak disebutkan domainnya disepakai sebagai fungsi real yaitu fungsi dengan domain dan kodomain himpunan bilangan real.

Fungsi adalah relasi. Relasi dapat disajikan dalam bentuk pasangan berurutan. Oleh karena itu, fungsi juga dapat dinyatakan sebagai pasangan berurutan. Karena relasi merupakan himpunan, fungsi juga dapat dipandang sebagai himpunan yang anggotanya adalah pasangan berurutan. Fungsi dapat digambarkan sesuai plot pasangan berurutan.
Gambaran fungsi merupakan modal awal untuk memahami konsep-konsep dan prosedur-prosedur yang mengikutinya. Memahami konsep dan prosedur dengan menggunakan gambaran yang mengikuti menunjukkan bahwa mahasiswa telah berpikir visual. Berpikir visual adalah berpikir dengan menggunakan gambaran mental. Hal ini sesuai penjelasan Darmadi (2012) tentang perlunya membangun pembelajaran matematika yang menyenangkan dengan visualisasi.

Dalam memahami konsep dan prosedur integral Riemann, mahasiswa perlu berpikir visual. Darmadi (2015) menjelaskan bahwa untuk memahami dengan visualisi adalah dengan mengenali, membayangkan, memperlihatkan, dan menyimpulkan. Tanpa mengetahui gambaran konsep dan prosedur yang dilakukan, mahasiswa akan menjadi cenderung hafalan tanpa memahami makna yang dilakukan sebenarnya.

Langkah-langkah yang diperlukan untuk pembuktian suatu fungsi terintegral 
secara Riemann adalah menggambarkan grafik fungsi, menentukan partisi, menentukan delta $\mathrm{x}_{\mathrm{i}}$, menentukan $\mathrm{M}_{\mathrm{i}}$ dan $\mathrm{m}_{\mathrm{i}}$, menentukan jumlah Riemann atas dan jumlah Riemann bawah, mencari integral Riemann atas dan integral Riemann bawah, kemudian membandingkan. Jika integral Riemann atas sama dengan integral Riemann bawah, maka fungsi itu terintegral. Membuktikan keintegralan suatu fungsi merupakan suatu masalah dalam analisis real. Darmadi \& Benny Handoyo (2016) menjelaskan bahwa untuk menyelesaikan masalah dengan visualisasi adalah sesuai pendapat Polya yaitu memahami, merencanakan, melaksanakan, dan memeriksa kembali.

Langkah awal dalam memahami konsep integral Reimann adalah menggambar grafik. Kekayaan pembayangan mental tentang grafik fungsi sangat dibutuhkan untuk memahami konsep integral Riemann. Permasalahan-permasalahan berpikir visual terjadi ketika mahasiswa mengalami kesalahan dalam menggambar grafik fungsi. Seperti yang dijelaskan Darmadi (2011) tentang imajeri mahasiswa dalam pembelajaran analisis real, maka perlu dilakukan identifikasi terhadap kesalahan-kesalahan mahasiswa dalam menggambar grafik fungsi dan menganalisis faktor-faktor penyebab terjadinya kesalahan dalam menggambar grafik fungsi. Dengan demikian, permasalahan-permasalahan berpikir visual dapat diminimalisir.

\section{Metode Penelitian}

Metode penellitian yang digunakan untuk menganalisis kesalahan berpikir mahasiswa dalam menggambarkan grafik fungsi adalah penelitian kualitatif deskriptif. Metode penelitian ini digunakan karena hasil identifikasi terhadap kesalahan-kesalahan mahasiswa dalam menggambar grafik fungsi dan menganalisis faktor-faktor penyebab terjadinya kesalahan dalam menggambar grafik fungsi disajikan secara deskriptif berdasarkan data yang alami.

Data diambil dari mahasiswa semester 7 program studi pendidikan matematika FKIP Universitas PGRI Madiun tahun akademik 2017/2018 kelas C. Terdapat 18 mahasiswa yang ikut berpartisipasi dalam penelitian ini.

Wawancara dan observasi berbasis tes dilakukan untuk pengumpulan data. Tes yang digunakan yaitu meminta mahasiswa untuk menggambarkan grafik fungsi

$$
f(x)=\left\{\begin{array}{l}
x^{2} \text { untuk } x \neq 0 \\
1 \text { untuk } x=0
\end{array}\right.
$$$$
\text { dan } f(x)=\left|x^{2}-2\right|
$$

Mahasiswa diingatkan bahwa tes tidak mempengaruhi nilai sehingga mahasiswa bebas untuk mengerjakan tanpa tekanan takut salah dan meniru teman yang lain.

Analisis data dilakukan dengan mengidentifikasi kesalahan - kesalahan mahasiswa dalam menggambarkan grafik dan menganalisis faktor - faktor penyebab terjadinya kesalahan-kesalahan tersebut.

\section{Hasil Penelitian dan Pembahasan}

Berdasarkan hasil tes, wawancara, dan observasi terhadap mahasiswa diteridentifikasi kesalahan - kesalahan mahasiswa dalam menggambar grafik fungsi sebagai berikut.

1. Kesalahan konsep fungsi real

Telah menjadi kesepakatan bahwa jika fungsi tanpa diberikan atau dibatas domain dan kodomainnya maka fungsi tersebut adalah fungsi real. Fungsi real adalah fungsi dengan domain dan kodomain himpunan bilangan real. Kesalahan dalam memahami konsep fungsi real tampak seperti pada gambar grafik berikut. 

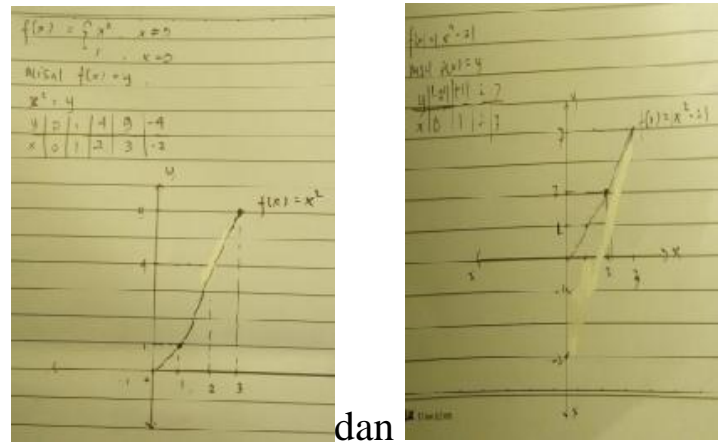

Pada kasus di atas, mahasiswa hanya mengeplotkan untuk domain bilangan non negatif $[0, \infty)$, tidak memperhatikan bahwa domainnya adalah himpunan bilangan real yaitu $(-\infty, \infty)$. Kesalahan dalam memahami konsep fungsi real dialami oleh $5,6 \%$ mahasiswa.

2. Kesalahan konsep fungsi sebagai pemetaan Fungsi dikenal juga pemetaan yaitu memetakan semua anggota dengan tepat satu ke anggota kodomain. Bukan sebaliknya. Kesalahan konsep fungsi sebagai pemetaan tampak seperti gambar jawaban mahasiswa berikut.
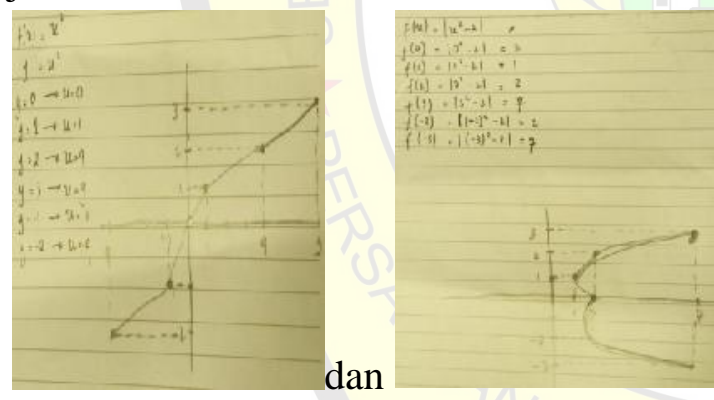

Fungsi dikenal dengan pemetaan. Misalkan fungsi $f$ dengan $f(x)=\mid x^{2}-$ 2|, maka $f(x)$ disebut sebagai peta dari $x$. Artinya nilai $f(x)$ ditentukan oleh nilai $x$. Sehingga, untuk mengeplotkan nilai $f(x)$ ditentukan oleh nilai $x$. Pada kasus di atas, mahasiswa menentukan nilai $f(x)$ lebih dulu untuk mendapatkan nilai $x$. Kesalahan konsep fungsi sebagai pemetaan ini dialami oleh 5,6\% mahasiswa.

3. Kesalahan dalam menggambarkan fungsi kuadrat
Kebiasaan dapat mempengaruhi pemikiran dan jawaban mahasiswa. Kebiasaan menggambar grafik fungsi linear terbawa untuk menggambarkan grafik yang non linear seperti persamaan kuadrat. Kesalahan dalam menggambarkan fungsi kuadrat tampak seperti jawaban mahasiswa berikut.
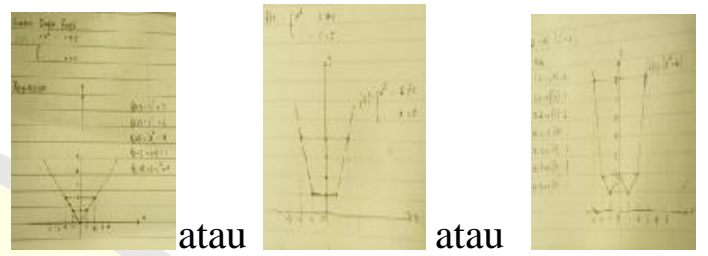

Fungsi kuadrat mestinya berbeda dengan fungsi/linear. Meskipun hanya sketsa, grafik fungsi kuadrat memiliki bentuk grafik yang tidak linear. Pada kasus di atas, mahasiswa menggambarkan grafik sebagai garis lurus tanpa memperhatikan bahwa grafiknya adalah untuk fungsi kuadrat. Kesalahan dalam menggambarkan fungsi kuadrat ini dilami oleh 29,4\% mahasiswa.

4. Kesalahan karena kurang teliti

Ketilitan atau kecermatan merupakan ketrampilan yang ditanamkan dalam pembelajaran matematika. Namun sebagai manusia dan mahasiswa, dalam mengerjakan sesuatu hal terkadang dapat tidak atau kurang teliti. Kesalahan karena kurang teliti tampak seperti jawaban mahasiswa berikut.
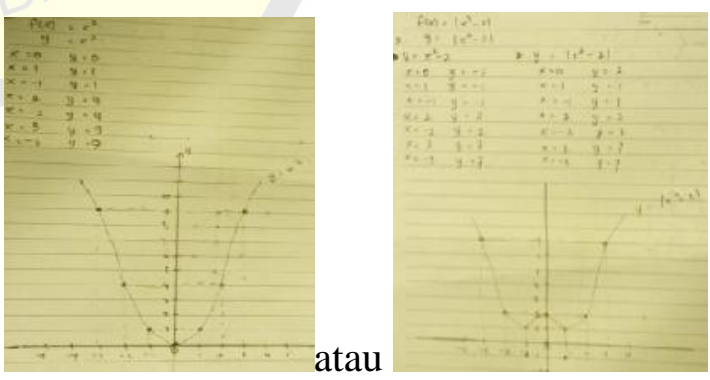

Memperhatikan domain dengan teliti sangat perlu untuk mendapatkan gambaran grafik yang benar. Pada gambaran 1, mahasiswa kurang teliti bahwa untuk $\mathrm{x}=1$ 
nilai $\mathrm{f}(\mathrm{x})=1$. Pada gambaran ke 2, mahasiswa kurang teliti untuk memeriksa nilai untuk grafik yang berpotongan dengan sumbu X. Kesalahan karena kurang teliti pada domain dialami oleh $53,8 \%$ mahasiswa.

5. Kesalahan karena terpengaruh

Kepadatan dalam kelas mempengaruhi pemikiran, kinerja, atau jawaban mahasiswa. Hal tersebut terjadi karena adanya proses interaksi yang terjadi tanpa dapat dikendalikan. Kepadatan mahasiswa terjadi karena mahasiswa lebih suka bergerombol atau berkumpul untuk mendapatkan rasa nyaman dalam belajar. Kesalahan karena terpengaruh tampak terjadi seperti pada gambar berikut.

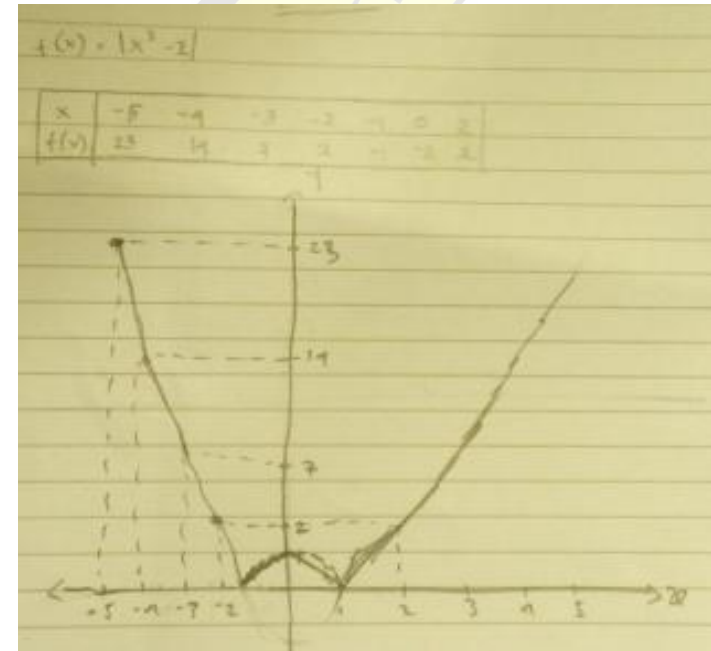

Tampak bahwa sebenarnya jawabannya dan proses awalnya benar yaitu menggambar grafik fungsi $f(x)=x^{2}-2$ yang kemudian grafik yang dibawah sumbu $X$ dicerminkan oleh sumbu $X$ ke atas sehingga semua nilai $f(x) \geq 0$. Namun karena teman-teman sekitarnya mempunyai gambaran yang linear, maka jawaban mahasiswa ini untuk grafik fungsi sekitar titik pusat 0 tampak terpengaruh menjadi linear. Kesalahan karena terpengaruh dialami oleh 5,6\% mahasiswa.

\section{Simpulan dan Saran}

\section{Simpulan}

Berdasarkan uraian di atas, dapat diperoleh kesimpulan sebagai berikut.

1. Kesalahan konsep fungsi real yaitu mahasiswa hanya mengeplotkan untuk domain bilangan non negatif $[0, \infty)$ yang dialami oleh 5,6\% mahasiswa.

2. Kesalahan konsep fungsi sebagai pemetaan yaitu mahasiswa menentukan nilai $f(x)$ lebih dulu untuk mendapatkan nilai $x$ yang dialami oleh 5,6\% mahasiswa.

3. Kesalahan dalam menggambarkan fungsi kuadrat yaitu mahasiswa menggambarkan grafik sebagai garis lurus tanpa memperhatikan bahwa grafiknya adalah untuk fungsi kuadrat yang dialami oleh 29,4\% mahasiswa.

4. Kesalahan karena kurang teliti yaitu mahasiswa kurang teliti dalam sesuatu atau beberapa hal yang dialami oleh $53,8 \%$ mahasiswa.

5. Kesalahan karena terpengaruh yaitu terjadi karena adanya proses interaksi dialami oleh $5,6 \%$ mahasiswa.

\section{Saran}

Saran yang dapat disampaikan bagi dosen adalah agar tidak terlalu fokus dalam formalitas matematika tetapi juga perlu mengembangkan kekayaan imjery atau pembayangan mental mahasiswa tentang grafik fungsi.

\section{Daftar Pustaka}

Darmadi (2011). "Imajeri Mahasiswa Dalam Pembelajaran Analisis Real (Studi Kasus Di IKIP PGRI MADIUN)". Makalah 
disajikan pada Seminar Nasional UNY, Jogjakarta, 3 Desember 2011

Darmadi (2012). “Membangun Pembelajaran Matematika yang Menyenangkan dengan Visualisasi". Makalah disajikan pada Seminar Nasional UNY, Jogjakarta, 24 Maret 2012

Darmadi (2015). "Profil Berpikir Visual Mahasiswa Calon Guru Matematika dalam Memahami Definisi Formal Berdasarkan Perbedaan Gender". Disertasi, UNESA, Surabaya

Darmadi (2016). "Profil Berpikir Visual Mahasiswa Calon Guru Matematika dalam Menyelesaikan Masalah Trigonometri', Jurnal Math Educator Nusantara, ISSN: 2459-97345, Volume 2 Nomor 2, Hal 1-93, Mei 2016, Program Studi Pendidikan Matematika, FKIP Universitas Nusantara PGRI Kediri 